\title{
THE CONTRACT OF EMPLOYMENT AND THE RIGHTS OF EMPLOYEES IN ALBANIA*
}

Edvana TIRI*

\begin{abstract}
The purpose of this paper is precisely the theoretical-practical treatment of the employment contract under the Labor Code. The employment contract is an important legal instrument. The parties in agreement with each other determine their rights and obligations. The contract has great importance for the employer and it is necessary for him to be recognized with his position in the company and institution. This paper will try to express the concept and the importance of the employment contract and the rights of employees by regulating their relationship through the employment contract.

Keywords: Contract; employees; employer; agreement; Labour Code
\end{abstract}

DOI: 10.53373 / REDS.2021.52.3.024

\section{The legal nature of employment contract in Albania}

Employment in Albania is largely governed and regulated by the 1995 Labour Code and which is based on the Albanian Constitution and is in accordance with all international conventions ratified by Albania. The Labour Code provides for the contractual regulation of the employment relationships between the employer and the employee by means of an individual or a collective labour agreement. The employment contract is a special kind of contract. It is a contract because it is an agreement between parties expressing their willingness to enter into a relationship and all the rights and obligations of the parties, but is special because of its great importance which affects the life of the employee. So the State and its laws, as also international legal acts have "framed" the freedom to contract an employment contract in order to protect the employee and the employer. The role of laws and other legal acts is to impose some standards to be achieved, which are necessary to develop a healthy employment relationship. An employment contract cannot be discriminatory or cannot contain severe conditions than those provided by law, for example lower wage than the minimum wage specified. ${ }^{1}$

The contract of employment is an agreement between the employers and the employees, which regulates the labor relations, and contains the rights and

\footnotetext{
* Paper presented at the International Conference "The future of labor law after coronavirus" organized on-line by the Association for the Study of Professional Labor Relations on May 13 and 14, 2021.

** Lecturer PhD of University Aleksandër Moisiu, Durres, Albania.

${ }^{1}$ Ergysa Ikonomi Good Faith Principle And The Employment Contract In Albania, Retrieved from https://macrotheme.com/yahoo_site_admin/assets/docs/8MR41ls.802442.pdf
} 
obligations of both parties. Through the Contract of Employment, the employee undertakes to offer his/her services for a fixed or unfixed period of time within the framework of the organization and orders of another person who is called employer, and who undertakes to pay a given remuneration.

The contract of employment may be concluded or changed either orally or in a written form. It may be changed only if the parties agree to do so. Any change of the written contract to the detriment of the employee must be executed in a written form.

The contract of employment is considered as concluded when the employer accepts the carrying out of a job for a definite or indefinite period of time within the framework of his/her organization and under his/her orders, and which, on the basis of these circumstances, is carried out against payment.

When the labour contract is concluded verbally, the employer is obliged to draw up, within 30 days from the date of the conclusion of the contract, in writing the relevant document, signed by him / her and the employee, including the elements outlined above. Failure to comply with this written document does not affect the validity of the contract, but only incurs the employer's liability ${ }^{2}$.

The Albanian Labour Code provides an extensive safeguard to employees within the framework of the employment relationship. It provides for, but is not limited to, the establishment of key rights and obligations of employer and employees and key features that the employment contract should include, with a view to specifying them and ensuring their presence in the framework of the employment relationship and for establishing the working conditions to be offered to the employee.

The Albanian regulatory framework indeed is based on concepts of employee and the employment contract to such an extent that not only are contractual matters key to such a relationship, but they aim at the synchronization and not mere coordination of the legal provisions. However, the application of differing criteria in the legislation, to describe an employment contract may be duly reconciled with different laws and legal contexts applied to employment in Albania. The various characterisations of an employment contract within the labour code are very diverse.

The reason for such a characterization is that the term employee generally determines the scope of a legal text, namely the set of laws governing the employment contract. ${ }^{3}$

The employment contract must not contradict the imperative provisions of the Labor Code, the Civil Code, the legislation of the Republic of Albania and the international one ratified and approved by the Republic of Albania. The cases of absolute invalidity of the employment contract are as follows:

The employment contract is in conflict with a mandatory provision of law.

\footnotetext{
${ }^{2}$ Labour Code of Republic of Albania, Article 202, paragraph http://www.qbz.gov.al/Kode/Kodi\%20i\%20Punes2018.pdf

${ }^{3}$ Enik Pogace, Application of EU labour acquis principles in Albanian employment contracts, Retrieved from https://www.iicj.net/subscribersonly/14september/iicj1sept-employment-enikpogace-albania.pdf
} 
It is not necessarily required that the cause of absolute invalidity be expressly provided for in law, but it is sufficient that an imperative provision of law has been violated. Condito sine qua non is only that objectively the employment contract is contrary to law.

- The employment contract is entered into to defraud the law.

The employment contract, from a formal point of view, may not be in conflict with the law, but, nevertheless, its content may contain an illegal legal action or consequence.

- The employment contract is entered into by a minor under 14 years of age. The employment contract cannot be concluded by entities that do not have full capacity to act or legal capacity

A fictitious or simulated employment contract is a legal action in which the will shown does not match the real will. This is a special case of absolute invalidity of the Employment Contract. An employment contract is fictitious when it is not intended to have legal consequences, while an employment contract is simulated when it is entered into to cover another legal action which is called a simulated action.

The Labor Code of the Republic of Albania in its Chapter V, explicitly provides for some other types of employment contracts, which in our doctrine are not named nonstandard forms of labor relations, but simply as types of employment contracts. The first contract is the group contract, part-time employment contract, work at home, commercial agent, vocational training contract, probationary employment contract. Labor Code of the Republic of Albania in its Chapter V explicitly provides for some other types of employment contracts, which in our doctrine are not named non-standard forms of employment relationships, but simply as types of employment contracts. The first contract is individual contract of employment, the collective contract of employment, the part-time employment contract, the work at home, the commercial agent, the vocational training contract, the probationary employment contract.

\section{The rights of employees}

The right to employment is sanctioned in the Constitution, specifically in Article 49 "Everyone has the right to earn the means of living by lawful work that he has chosen or accepted himself." $\mathrm{He}$ is free to choose his profession, work place and the system of his professional qualification ". This principle applies to all citizens, for men and women. In fact, this makes the Constitution to be regarded as neutral in terms of gender. So, for the implementation of the principle of prohibition of discrimination there can not be tolerated any kind of discrimination in the field of employment and the exercise of the profession ${ }^{4}$

\footnotetext{
${ }^{4}$ Ilir Rusi, The Albanian legal framework on non-discrimination and gender equality in employment relationships Retrieved from http://www.academicus.edu.al/nr5/Academicus-MMXII-5-131-142.pdf
} 
Albania has adopted the law on protection from discrimination which law has fully approximated, among others, the Council Directive for equal treatment in employment and occupation. The law ensures the rights of employees for equality before law, equality in opportunities as well as provides effective protection from discrimination.

A special provision in this law addresses the prohibition of discrimination in relation to announcement of vacancies, recruitment and selection of employees as well as equal treatment at work. In addition it provides for the responsibility of the employer to comply with the law requirements, to address the claims raised in the basis of discrimination practices as well as to take an active role in raising the awareness and proper understanding on non-discrimination rules and procedures.

Pursuant to the recommendations issued by Commissioner on Protection from Discrimination (CPD), the recent changes made to Labour Code mark an improvement as regards the non-discrimination regulations in labour relationships. In this regard, Labour Code has fully approximated the related provisions of the Council Directive on establishing a general framework for equal treatment in employment and occupation, the Council Directive implementing the principle of equal treatment between persons irrespective of racial or ethnic origin as well as of the Directive on the implementation of the principle of equal opportunities and equal treatment of men and women in matters of employment and occupation (recast) $)^{5}$.

Equal opportunity and treatment at work between all persons is based on the principle of equal treatment between persons irrespective of racial or ethnic origin. The new regulations made in Labour Code prohibit all types of discrimination. It literally provides for the right of each employee to be equally treated based on their qualifications and performance in terms of education effort and level of responsibility without discrimination on the grounds of: gender, ethnicity, colour, language, gender identity, sexual orientation, disability, health status, social origin, national origin or religion, philosophic or political opinion, economic, education and social situation, maternity, parental background, parental responsibility, age, marital or family status, civil status, residence, health status, genetic predispositions, disability, living with HIV/AIDS, joining or belonging to labour organizations, belonging to a particular group, or any other reason, that aims or causes to prevent or make impossible the exercise of the right of employment and occupation, in the same way as others.

Albania has also ratified a number of Conventions with regard to protection of women's rights such as Convention on the Elimination of all Forms of Discrimination towards Women, International Convention on Civic and Political Rights, International Convention on Economic, Social and Cultural Rights and European Convention on Human Rights. Equal treatment refers to equal entitlements like equal payment and compensation. While the existing regulation refers to equal

\footnotetext{
${ }^{5}$ Aleka Papa, Zyhrada Kongoli, Labour Standarts in Albania, Research Report, Institute for Democracy and Mediation, 2016, pg,19
} 
remuneration between sexes, the recent changes made to the Labour Code have expanded the scope of equal remuneration by making reference to any form of discrimination, direct or indirect one, relating to all aspects and conditions of remuneration for equal work or work of equal value. In this view the related provisions have been elaborated by widening the non-discriminatory ground.

The issue of foreign employees' rights is also addressed by the recent changes of the Labour Code. The employment relation of foreigners is based in the principle of equal treatment with national employees. The employment relationship for foreigner workers is regulated by the provisions of the Albanian legislation and only if the Albanian regulation is less favorable than the legislation of the exporting country, the more favorable legislation for the employee shall apply.

The equal treatment of workers employed with defined employment contract duration has also attained a particular attention of the changes made to Labour Code. ${ }^{6}$ They enjoy proportionally equal rights. This category of employees cannot be treated in less favorable way compared to workers with undefined employment contract duration as regards employment conditions, training and career opportunities at work.

Albania ratified Convention No. 138 on the Minimum Age in 1998 and Convention No. 182 on the Worst Forms of Child Labour in 2001. The law sets the minimum age of employment at 14 years and regulates the amount and type of labour that children under the age of 18 may perform. However, per section 100(2) of the Labour Code young persons from 16 years of age may be employed in difficult or hazardous work, under conditions determined by decree that limit working hours and may regulate working conditions. The ILO CEACR has expressed deep concern at the grave situation of children begging on the streets in Albania, who are particularly exposed to the worst forms of child labour. Forced Labour Albania ratified Convention No. 29, the Forced Labour Convention, in 1957 and Convention No. 105 on the Abolition of Forced Labour in $1997 .{ }^{7}$

As regards the duration of working time for children, the Labour Code limits the length of working time for employees to maximum 6 hours per day. The nighttime work is prohibited for employees under age 18.

Law on protection of child rights also affects the child labour standard. The prevention of child work is covered by the definition on child protection. The law also deals with the protection of the children from economic exploitation as well as from performing every kind of work that is forced, presents risks, affects education, damages health and impairs physical, mental, spiritual, moral or social development of the child.

The children rights protection law pays a particular attention to the category of children with disabilities to ensure an effective access in education, training, health care and rehabilitation services as well as their preparation for employment and entertainment.

\footnotetext{
${ }^{6}$ Idem pg.21

${ }^{7}$ Eda Gjoka, Child Labor: International Standards And Albanian Legislation,Retrieved from Retrieved from http://www.asecu.gr/files/13th_conf_files/Child-Labor-International-Standards-and-Albanian-Legislation.pdf
} 
This is done with the aim of developing opportunities in a favorable manner, in order to achieve a full social, cultural and spiritual integration for children with disabilities.

Maternity protection standard in work relationship is addresses mainly in the Labour Code as well as in the law on security and health at work. The Labour Code provides for a special protection for women before and after giving birth. In any case, the termination of employment contract during maternity leave is invalid. In addition to that the Labour Code provides regulation for particular rights during maternity period.

The Labour Code regulations regarding maternity protection relate to the prohibition of work for women 35 days before giving birth and at least 63 days after giving birth. The prohibition period after giving birth has been 42 days and has been extended upon recent changes to Labour Code. In addition to that, the recent changes have approximated the Council Directive on introduction of measures to encourage improvements in the safety and health at work of pregnant workers those who have just given birth and/or are breastfeeding.

The Labour Code provisions govern the establishment and the rights of the trade unions and professional organizations of employers and employees. It also has to be noted that freedom of association is a right guaranteed by the Albanian Constitution. Trade unions and professional organization should submit the act of incorporation and the by laws with the First Instance Court of Tirana, in order to acquire legal personality. Trade unions represent their members in negotiations of the collective contracts with the employers, as well as in negotiations regarding the change of terms and conditions of the existing collective employment contracts. Trade unions are further entitled to protect the interests of their members before the courts; in order to oblige, the employer has to observe the provisions of the employment legislation, collective employment contract or individual employment contracts.

\section{Conclusion}

The employment contract is defined in the Labour Code as an agreement between the employee and the employer. The employee undertakes to offer his work or service for a certain or indefinite period of time, in the framework of organizing the orders of another person called the employer. The employer undertakes to pay a reward.

The individual employment contract is a bilateral legal action and a bilateral contract, the will for mutual obligations between the parties. In this context, the employment contract belongs to the category of contracts with mutual actions, which means that the obligations and rights of the parties are bilateral.

The Labour Code, which is the main law that provides for labour rights, obliges employers to comply with a variety of rules towards meeting the labour standards. In particular, the Labour Code lays down the employees rights as regards the equal 
treatment and non-discrimination, safety and health at work, special protection for women and children and maternity protection.

Beyond the critical situation in the health system, Covid-19 revealed and worsened the deep crisis in the world of work and the structural weaknesses of the development model of these three decades.

The pandemic revealed and worsened the structural problems of the working world in Albania. Therefore, a more complete assessment of the intensity of the crisis caused by Covid 19 cannot be made detached from these problems. Thus, Covid 19 infections in the workplace but also the numerous accidents at work during the pandemic period, are directly related to the weaknesses of the protection system and health at work.

It is already a widely accepted fact that not only poverty but also inequality are closely linked to structural problems in the world of work. More specifically for our region, a recent study by the Friedrich Ebert Stiftung emphasizes that labor markets are the main cause of inequality and that income inequality is caused especially by unemployment, non-participation in economic activities, informal work and precarious conditions, but also by lack of progressive taxation systems and weakness of social protection systems In 2018, more than one in three people in Albania was poor and various studies suggest high levels of inequality in the country. The pandemic crisis will increase unemployment and will throw even more workers into the informal economy. At the same time, the crisis will exacerbate wage pressure.

Wage-cutting practices reported during the pandemic are likely to continue even more massively considering the pressure from rising unemployment levels, but also the fact that most workers are disorganized into real unions, which would be able to protect them.

\section{Bibliography:}

\section{Books}

1. Aleka Papa, Zyhrada Kongoli, Labour Standarts in Albania, Research Report, Institute for Democracy and Mediation, 2016

2. Kudret Cela, E drejte e Punës, Botimi XV, Tiranë 2014

3. Kudret Cela, Kontrata Individuale e Punës, Tiranë 2013

\section{Legislation}

1. The Constitution of the Republic of Albania, approved by law no. 8417, 21.10.1998

2. Law no.7961, dated 12.07.1995, "Labor Code of the Republic of Albania", amended

3. Law no. 136/2015, "Some additions and changes to law no. 7961/1995, "Labor Code of the Republic of Albania", amended

4. Direction no. $78 / 2000$ of the EU 'The establishment of a regulatory framework for equal treatment in employment relations'

5. Law no. $10237 / 2010$, "Safety and health at work"

6. Law no. 10347/2010, The protection of the rights of the child"

7. Law no. $10221 / 2010$ " The protection from discrimination" 